\title{
Adoptive transfer of $T$ cells transduced with a chimeric antigen receptor to treat relapsed or refractory acute leukemia: efficacy and feasibility of immunotherapy approaches
}

\author{
Guoliang Ding \& Hu Chen* \\ Department of Hematopoietic Stem Cell Transplantation, Affiliated Hospital of Academy of Military Medical Sciences, Beijing 100853, China
}

Received January 19, 2016; accepted March 25, 2016; published online April 29, 2016

\begin{abstract}
Treatment outcomes of acute leukemia (AL) have not improved over the past several decades and relapse rates remain high despite the availability of aggressive therapies. Conventional relapsed leukemia treatment includes second allogeneic hematopoietic stem cell transplantation (allo-HSCT) and donor lymphocyte infusion (DLI), which in most cases mediate, at best, a modest graft-versus-leukemia effect, although their clinical efficacy is still limited. Although allo-HSCT following myeloablative conditioning is a curative treatment option for younger patients with acute myeloid leukemia (AML) in a first complete remission (CR), allo-HSCT as a clinical treatment is usually limited because of treatment-related toxicity. The overall DLI remission rate is only $15 \%-42 \%$ and 2-year overall survival (OS) is approximately $15 \%-20 \%$, with a high (40\%-60\%) incidence of DLI-related graft-versus-host disease (GVHD). Therefore, development of new, targeted treatment strategies for relapsed and refractory AL patients is ongoing. Adoptive transfer of $\mathrm{T}$ cells with genetically engineered chimeric antigen receptors (CARs) is an encouraging approach for treating hematological malignancies. These $\mathrm{T}$ cells are capable of selectively recognizing tumor-associated antigens and may overcome many limitations of conventional therapies, inducing remission in patients with chemotherapy-refractory or relapsed AL. In this review, we aimed to highlight the current understanding of this promising treatment modality, discussing its adverse effects and efficacy.
\end{abstract}

chimeric antigen receptor, acute leukemia, efficacy, feasibility

Citation: Ding, G., and Chen, H. (2016). Adoptive transfer of T cells transduced with a chimeric antigen receptor to treat relapsed or refractory acute leukemia: efficacy and feasibility of immunotherapy approaches. Sci China Life Sci 59, 673-677. doi: 10.1007/s11427-016-0017-3

\section{INTRODUCTION}

Allo-HSCT and chemotherapy have been used to successfully treat patients with acute lymphoblastic leukemia (ALL), but the prognosis of adult patients with relapsed ALL is still very poor. Long-term survival rate of adult patients with relapsed ALL depends on the achievement of $\mathrm{CR}$, induced through chemotherapy, followed by allo-HSCT (Fielding et al., 2007; Gokbuget et al., 2012). Unfortunately, many patients will not receive allo-HSCT because of a fail-

*Corresponding author (email: chenhu217@aliyun.com) ure in achieving second CR following salvage chemotherapy. For patients with AML, the probability of being cured with chemotherapy alone is significantly lower than combined treatment, as only 50\%-65\% patients achieve longterm survival (Gibson et al., 2005; Lange et al., 2008; Creutzig et al., 2008). Moreover, the prognosis is even worse in elderly patients (Kaspers et al., 2006; Appelbaum et al., 2006).To address the problem of limited therapeutic success of treating relapsed/refractory ALL or AML, adoptive therapy with chimeric antigen receptor expressing $\mathrm{T}$ (CAR-T) cells is a promising approach for hematologic malignancies. 


\section{CAR: GENETICALLY MODIFIED ADOPTIVE CELL THERAPY}

CAR-T cells were first described as an adoptive cell therapy in 1989 by Gross and colleagues (Gross et al., 1989). CARs are composed of an extracellular domain that recognizes tumor surface antigens and is linked to an intracellular signaling domain via trans-membrane domains. The extracellular domain consists of antigen-binding variable regions from monoclonal antibody heavy and light chains that are fused into a single protein known as the single-chain variable fragment (Dotti et al., 2014; Jena et al., 2010). Firstgeneration CAR contained a single-signaling domain derived from either TCR- $\zeta$ or FcR- $\gamma$ chain (Eshhar et al., 1993; Moritz et al., 1994). Second-generation CAR included a single co-stimulatory domain derived from either 4$1 \mathrm{BB}$ or CD28. Third-generation CAR had two co-stimulatory domains, namely 4-1BB and CD28, and other co-stimulatory molecules (Goker et al., 2016). T cell genetic modification with CAR has several advantages in leukemia treatment, e.g., CAR use is applicable to a broad range of patients irrespective of the HLA phenotype. CAR-T cell approach also overcomes ability of the tumor to escape immunosurveillance by down-regulating HLA molecules on cell surface. Targeting of tumor antigens with CAR-T cells is applicable to any tumor antigens, including glycolipids, proteins, and carbohydrates. CAR-T cell clinical trials are currently conducted.

\section{ONGOING TRIALS OF TREATING AL PATIENTS WITH CAR-T CELLS}

Until now, 30 CAR-T AL trials have been published. Some of these focused on ALL, targeting CD19 or CD20, whereas others focused on AML, targeting Lewis-Y antigen or CD33. The results are summarized in Table 1.

\section{PUBLISHED CLINICAL OUTCOMES OF ADOPTIVE THERAPY WITH CAR-MODIFIED T CELLS FOR ALL}

Relapsed ALL is difficult to treat despite the availability of aggressive therapies. Promising results have been obtained in recent studies on CD19/CD20-targeted CAR-T (CD19/ CD20-CAR-T) for ALL treatment (Kochenderfer et al., 2012). Maude and colleagues conducted research into infusing autologous $\mathrm{T}$ cells transduced with CD19-targeted CAR (CD19-CAR-T) in patients with relapsed or refractory ALL. Patients were monitored for clinical response and toxic effects. The clinical results revealed that $\mathrm{CR}$ was achieved in $27(90 \%)$ out of 30 patients (children and adults). Sustained remission was achieved, with $67 \%$ 6-month event-free survival rate and $78 \%$ OS rate. Cytokine-release syndrome (CRS), which later developed in $27 \%$ patients, was associated with a higher disease burden.
Davila and colleagues examined 16 patients with relapsed or refractory B cell acute lymphoblastic leukemia (B-ALL) who were treated with CD19-CAR-T. Clinical results revealed $88 \%$ overall complete response rate. This therapy was as effective in treating high-risk patients with Philadelphia chromosome-positive $\mathrm{Ph}^{+}$disease, as in treating those with relapsed disease after previous allo-HSCT (Davila et al., 2014). Shortly afterwards, Lee and colleagues published outcomes of a clinical investigation concerning 21 patients with relapsed or refractory ALL (including eight who had previously undergone allo-HSCT) who were infused with CD19-CAR-T. Safety of the treatment was evaluated and any toxic effects were fully reversible, with the highest severity, Grade 4, CRS observed in 3 (14\%) out of 21 patients (95\% CI 3.0-36.3) (Lee et al., 2015). Thus, CD19-CAR-T therapy is feasible, safe, and mediates a potent anti-leukemic effect in patients with ALL.

\section{PUBLISHED CLINICAL OUTCOMES OF ADOPTIVE THERAPY WITH CAR-MODIFIED T CELLS FOR AML}

Despite the improvement in allo-HSCT and chemotherapy-based treatment of AML, the majority of standard or high-risk AML patients will die or relapse. AML is sensitive to T-cell-mediated control in the allo-HSCT setting. Nevertheless, therapeutic approaches directed at inducing autologous T-cell responses in patients have shown limited efficacy (Wen et al., 2002; Kershaw et al., 2006). Therefore, the development of novel therapeutics for treating AML is crucial. Although CD19-CAR-T approaches are proving highly effective against hematologic malignancies (Brenner et al., 2013), a concern has been raised that extending this success to other tumors may be difficult. CD19 antigen (Jensen et al., 2010) is generally restricted to the B cell lineage. In contrast, LeY antigen is a difucosylated carbohydrate antigen widely expressed by AML cells, but with a limited expression in healthy tissues. However, its role and significance for the survival of leukemia cells remain to be elucidated. In 2013, a phase I clinical trial was conducted at the Ludwig Institute for Cancer Research (Ritchie et al., 2013) examining autologous CAR-anti-LeY-T therapy for AML. Safety and post-infusion persistence of adoptively transferred T cells. Neither Grade 3 nor Grade 4 toxicities were observed. One patient achieved a cytogenetic remission whereas in another, with active leukemia, reduction in peripheral blood (PB) blasts was observed. This clinical outcome verified the safety and feasibility of CAR-T therapy in high-risk AML patients and demonstrated durable in vivo persistence. CD123, a trans-membrane chain of interleukin (IL)-3 receptor, is expressed in the majority of AML cells and in many normal cells. Recent preclinical reports have demonstrated that CAR-T cells have the potential to effectively and durably eradicate primitive myeloid blast cells (Mardiros et al., 2013). Mardiros and colleagues con- 
Table 1 Summary of ongoing clinical trials of autologous/allogeneic CAR-T cell treatments for AL

\begin{tabular}{|c|c|c|c|c|c|c|}
\hline Disease & Target antigen & Gene transfer & CAR signaling domain & Sponsor & $\begin{array}{l}\text { Clinical Trial.gov } \\
\text { ID }\end{array}$ & Status \\
\hline ALL & $\mathrm{CD} 20$ & Retrovirus & scFv-(4-1BB-CD3ל) & Chinese PLA General Hospital & NCT01735604 & Recruiting \\
\hline ALL & CD19 & Lentivirus & 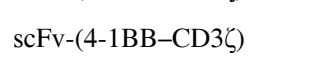 & $\begin{array}{l}\text { Penn Medicine's Abramson Cancer } \\
\text { Center }\end{array}$ & NCT00891215 & Completed \\
\hline ALL & CD19 & Lentivirus & scFv-(4-1BB-CD3ל) & University of Pennsylvania & NCT01551043 & Completed \\
\hline ALL & CD19 & Retrovirus & 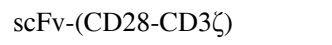 & Baylor College of Medicine & NCT00608270 & Recruiting \\
\hline ALL & CD19 & Retrovirus & 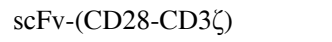 & Memorial Sloan KetteringCancer Center & NCT01416974 & Recruiting \\
\hline ALL & CD19 & Lentivirus & scFv-(4-1BB-CD3ל) & University of Pennsylvania & NCT02030847 & Recruiting \\
\hline ALL & CD19 & Lentivirus & 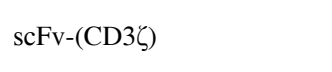 & $\begin{array}{l}\text { Fred Hutchinson Cancer } \\
\text { Research Center }\end{array}$ & NCT01475058 & Completed \\
\hline ALL & CD19 & Lentivirus & 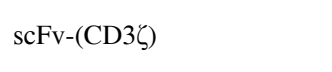 & $\begin{array}{l}\text { Fred Hutchinson Cancer } \\
\text { Research Center }\end{array}$ & NCT01865617 & Recruiting \\
\hline ALL & CD19 & Lentivirus & 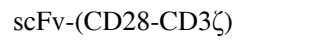 & City of Hope Medical Center & NCT02146924 & Recruiting \\
\hline AML & CD123 & Lentivirus & 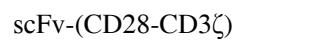 & City of Hope Medical Center & NCT02159495 & Recruiting \\
\hline ALL & CD19 & Retrovirus & 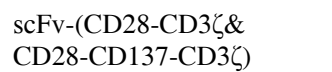 & Baylor College of Medicine & NCT01853631 & Recruiting \\
\hline ALL & CD19 & Retrovirus & $\mathrm{scFv}-(\mathrm{CD} 28-\mathrm{CD} 3 \zeta)$ & $\begin{array}{l}\text { Memorial Sloan Kettering } \\
\text { Cancer Center }\end{array}$ & NCT01840566 & Recruiting \\
\hline ALL & CD19 & $\begin{array}{l}\text { Retrovirus/ } \\
\text { Lentivirus }\end{array}$ & $\begin{array}{l}\mathrm{scFv}-(\mathrm{CD} 28-\mathrm{CD} 3 \zeta \& \\
4-1 \mathrm{BB}-\mathrm{CD} 3 \zeta)\end{array}$ & $\begin{array}{l}\text { Memorial Sloan Kettering } \\
\text { Cancer Center }\end{array}$ & NCT00466531 & Recruiting \\
\hline ALL & CD19 & Retrovirus & 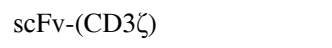 & University College London & NCT01195480 & Recruiting \\
\hline ALL & CD19 & Retrovirus & 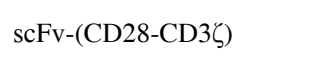 & $\begin{array}{l}\text { Memorial Sloan Kettering } \\
\text { Cancer Center }\end{array}$ & NCT01860937 & Recruiting \\
\hline ALL & CD19 & Retrovirus & $\mathrm{scFv}-(\mathrm{CD} 28-\mathrm{CD} 3 \zeta-4-1 \mathrm{BB})$ & Uppsala University & NCT02132624 & Recruiting \\
\hline ALL & CD19 & Lentivirus & 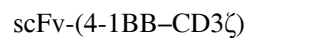 & Seattle Children's Hospital & NCT02028455 & Recruiting \\
\hline ALL & CD19 & Retrovirus & 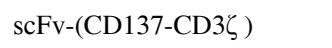 & Chinese PLA General Hospital & NCT01864889 & Recruiting \\
\hline ALL & CD19 & Transposon & 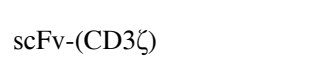 & MD Anderson Cancer Center & NCT01497184 & $\begin{array}{l}\text { Active, not } \\
\text { recruiting }\end{array}$ \\
\hline ALL & CD19 & Retrovirus & 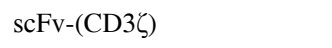 & National Cancer Institute & NCT01593696 & Recruiting \\
\hline AML & Lewis-Y & Retrovirus & 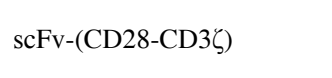 & $\begin{array}{l}\text { Peter MacCallum Cancer } \\
\text { Center }\end{array}$ & NCT01716364 & Unknown \\
\hline ALL & CD19 & Retrovirus & 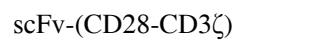 & National Cancer Institute & NCT00924326 & Recruiting \\
\hline ALL & CD19 & Retrovirus & $\mathrm{scFv}-(\mathrm{CD} 28-\mathrm{CD} 3 \zeta)$ & $\begin{array}{l}\text { Memorial Sloan Kettering } \\
\text { Cancer Center }\end{array}$ & NCT01044069 & Recruiting \\
\hline ALL & CD19 & Retrovirus & $\mathrm{scFv}-(\mathrm{CD} 3 \zeta)$ & $\begin{array}{l}\text { Memorial Sloan Kettering } \\
\text { Cancer Center }\end{array}$ & NCT01430390 & Recruiting \\
\hline AML & CD33 & Retrovirus & 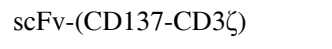 & Chinese PLA General Hospital & NCT01864902 & Recruiting \\
\hline ALL & CD19 & Lentivirus & 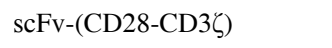 & Seattle Children's Hospital & NCT01683279 & Recruiting \\
\hline ALL & CD19 & Lentivirus & 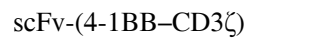 & University of Pennsylvania & NCT01747486 & Recruiting \\
\hline ALL & CD19 & Retrovirus & 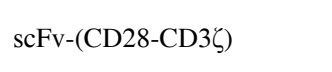 & Baylor College of Medicine & NCT00586391 & $\begin{array}{l}\text { Active, not } \\
\text { recruiting }\end{array}$ \\
\hline ALL & CD19 & Lentivirus & $\mathrm{scFv}-(4-1 \mathrm{BB}-\mathrm{CD} 3 \zeta)$ & University of Pennsylvania & NCT01626495 & Recruiting \\
\hline ALL & CD19 & Lentivirus & 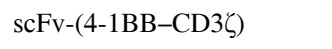 & University of Pennsylvania & NCT01029366 & Completed \\
\hline ALL & CD19 & Retrovirus & $\mathrm{scFv}-(\mathrm{CD} 3 \zeta)$ & Baylor College of Medicine & NCT00840853 & Recruiting \\
\hline ALL & CD19 & Transposon & 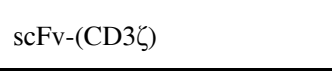 & MD Anderson Cancer Center & NCT01362452 & $\begin{array}{l}\text { Active, not } \\
\text { recruiting }\end{array}$ \\
\hline
\end{tabular}

ducted preclinical trials using autologous T cells transduced with CD123-targeted CAR (CD123-CAR-T) in infused AML xenograft model. Their data revealed a CD123-CART-mediated potent activity against $\mathrm{CD} 123^{+}$cell lines as well as primary AML samples. Additionally, CD123-CAR-T cells exhibited anti-leukemic activity in vivo in a xenogeneic AML model. Gill and colleagues suggested that CAR-T123-based myeloablation might be used as a novel conditioning regimen for hematopoietic cell transplantations (Gill et al., 2014).

\section{DISCUSSION}

A series of clinical trials point to key factors, including CAR-T cell design, different gene transfer approaches, and tumor burden, that impact efficacy of the CAR-T cell treatment of hematologic malignancies. Preclinical studies and clinical trials have demonstrated the advantage of CAR-T cell in vivo antitumor activity, enhanced by second- and third-generation CAR containing $\mathrm{T}$ cell co-stimulatory signaling domains, when compared with first-generation CAR 
(Brentjens et al., 2007; Teng et al., 2004). For example, 2014 work of Maude and colleagues (Maude et al., 2014) on second-generation CAR-T cells and ALL treatment, demonstrated superiority of this approach compared with earlier first-generation CAR-T cell experiments Furthermore, most investigators have been attempting different $\mathrm{T}$ cell gene transfer techniques influencing the efficacy of CAR-T cell applications. Retroviruses have been frequently used in ALL research because they efficiently and permanently transduce $\mathrm{T}$ cells, and preliminarily studies verified safety of this approach (Scholler et al., 2012). Lentiviral vectors also efficiently transduce $\mathrm{T}$ cells but are expensive to manufacture, yet potentially safer than retroviruses (Biffi et al., 2011). Investigators have seldom resorted to electroporation or transposon gene transfer technologies (Jin et al., 2011; Till et al., 2008). Alas, no published clinical studies directly compare the different gene transfer approaches, leaving open the question of whether clinically meaningful differences exist between these gene transfer vectors. Tumor burden was demonstrated to be yet another important factor in CAR-T efficacy in a 2011 study by Memorial Sloan-Kettering Cancer Center, where an inverse correlation was noted between tumor burden and the detectable infused modified T cells over time (Brentjens et al., 2011). Most trials focused on the protocols of allo-HSCT in combination with CAR-T cells, superior to CAR-T cell approach alone, until 2014, when Maus and colleagues hypothesized that CAR-T cells may replace allogeneic transplantation as a definitive therapy. Maude has published results of a clinical trial that verified this hypothesis (Maude et al., 2014): the event-free survival and OS of ALL patients who had previously undergone stem-cell transplantation were not different after CAR-T cell treatment than in ALL patients who have not received stem-cell transplantation. Integration of CAR-T with allo-HSCT in future treatment protocols is worth considering, and CAR-T and allo-HSCT timings are expected to be verified by future large sample randomized trials. CRS is also noteworthy. Investigators have shown that CRS was often accompanied by macrophage activation syndrome (MAS), which may be driven in part by high IL-6 levels (Grupp et al., 2013). In the above-mentioned clinical trials, most patients had some degree of CRS. It is not yet clear whether the severity of CRS or MAS is related to antitumor efficacy. In conclusion, CAR-T cell approach has been, undoubtedly, a breakthrough in leukemia treatment. Numerous international trials are currently under way to optimize, such as CAR design, integration protocol optimization, etc.

Compliance and ethics The author(s) declare that they have no conflict of interest.

Acknowledgements This work was supported by the Key New Drug Development and Manufacturing Program of the "Twelfth Five-year Plan" of China (2011ZX09102-001-29) and Clinical Application Research of Beijing (Z131107002213148).

Appelbaum, F.R., Gundacker, H., and Head, D.R. (2006). Age and acute myeloid leukemia. Blood 107, 3481-3485.

Biffi, A, Bartolomae, C.C, and Cesana, D. (2011). Lentiviral vector common integration sites in preclinical models and a clinical trial reflect a benign integration bias and not oncogenic selection. Blood 117, 5332-5339.

Brenner, M.K. (2013). CAR-T cells for acute myeloid leukemia: the LeY of the land. Mol Ther 21, 1983-1984.

Brentjens, R.J, Santos, E, and Nikhamin, Y. (2007). Genetically targeted T cells eradicate systemic acute lymphoblastic leukemia xenografts. Clin Cancer Res 13, 5426-5435.

Brentjens, R.J, Rivière, I., Park, J.H., Davila, M.L., Wang, X., Stefanski, J., Taylor, C., Yeh, R., Bartido, S, Borquez-Ojeda, O., Olszewska, M.,Bernal,Y., Pegram, H., Przybylowski, M., Hollyman, D., Usachenko, Y., Pirraglia, D., Hosey, J., Santos, E., Halton, E., Maslak, P., Scheinberg, D., Jurcic, J., Heaney, M., Heller, G., Frattini, M., and Sadelain, M. (2011). Safety and persistence of adoptively transferred autologous CD19-targeted T cells in patients with relapsed or chemotherapy refractory B-cell leukemias. Blood 118, 4817-4828.

Davila, M.L., Riviere, I., Wang, X., Bartido, S., Park, J., Curran, K., Chung, S.S., Stefanski, J., Borquez-Ojeda, O., Olszewska, M., Qu, J., Wasielewska, T., He, Q., Fink, M., and Shinglot, H. (2014). Efficacy and toxicity management of 19-28z CAR-T cell therapy in B cell acute lymphoblastic leukemia. Sci Transl Med 19, 224.

Dotti, G., Gottschalk, S., Savoldo, B., and Brenner, M.K. (2014). Design and development of therapies using chimeric antigen receptor-expressing T cells. Immunol Rev 257, 107-126.

Eshhar, Z., Waks, T., Gross, G., and Schindler, D.G. (1993). Specific activation and targeting of cytotoxic lymphocytes through chimeric single chains consisting of antibody-binding domains and the gamma or zeta subunits of the immunoglobulin and T-cell receptors. Proc Natl Acad Sci USA 90, 720-724.

Fielding, A.K., Richards, S.M., Chopra, R., Lazarus, H.M., Litzow, M.R., Buck, G., Durrant I.J., Luger, S.M., Marks, D.I., Franklin, I.M., McMillan, A.K., Tallman, M.S., and Rowe, J.M. (2007). Outcome of 609 adults after relapse of acute lymphoblastic leukemia (ALL), an MRC UKALL12/ECOG 2993 study. Blood 1093, 944-950.

Gibson, B.E., Wheatley, K., Hann, I.M., Stevens, R.F., Webb, D., Hills, R.K., De Graaf, S.S., and Harrison, C.J. (2005). reatment strategy and long-term results in paediatric patients treated in consecu tive UK AML trials. Leukemia19, 2130-2138.

Gill, S., Tasian, S.K., Ruella, M., Shestova, O., Li, Y., Porter, D.L., Carroll, M., Danet-Desnoyers, G., Scholler, J., Grupp, S.A., June, C.H., and Kalos, M. (2014). Preclinical targeting of human acute myeloid leukemia and myeloablation using chimeric antigen receptor-modified T cells. Blood 123, 2343-2354.

Gokbuget, N., Stanze, D., Beck, J., Diedrich, H., and Horst, H.A. (2012). Outcome of relapsed adult lymphoblastic leukemia depends on response to salvage chemotherapy, prognostic factors, and performance of stem cell transplantation. Blood 10, 2032-2041.

Goker H., Malkan U.Y., Demiroglu H., and Buyukasik Y. (2016). Chimeric antigen receptor $\mathrm{T}$ cell treatment in hematologic malignancies. Transfus Apher Sci 54, 35-40.

Creutzig, U., Büchner, T., Sauerland, M.C., Zimmermann, M., Reinhardt, D., Döhner, H., and Schlenk, R.F. (2008). Significance of age in acute myeloid leukemia patients younger than 30 years: a common analysis of the pediatric trials AML-BFM 93/98 and the adult trials AMLCG 92/99 and AMLSG HD93/98A. Cancer 112, 562-571.

Gross, G., Waks, T., and Eshhar, Z. (1989). Expression of immunoglobulin-T-cell receptor chimeric molecules as functional receptors with antibody-type specificity. Proc Natl Acad Sci USA 86, 10024-10028.

Grupp, S.A., Kalos, M., Barrett, D., Aplenc, R., Porter, D.L., Rheingold, S.R., Teachey, D.T., Chew, A., Hauck, B., Wright, J.F., Milone, M.C., 
Levine, B.L., and June, C.H. (2013). Chimeric antigen receptor-modified T cells for acute lymphoid leukemia. N Engl J Med 368, 1509-1518.

Kaspers, G.J., and Creutzig, U. (2006). Pediatric acute myeloid leukemia: international progress and future directions. Leukemia 19, 2025-2029.

Lange, B.J., Smith, F.O., Feusner, J., Barnard, D.R., Dinndorf, P., Feig, S., Heerema, N.A., Arndt, C., Arceci, R.J., Seibel, N., Weiman, M., Dusenbery, K., Shannon, K., Luna-Fineman, S., Gerbing, R.B., and Alonzo, T.A. (2008). Outcomes in CCG-2961, a children's oncology group phase 3 trial for untreated pediatric acute myeloid leukemia: a report from the children's oncology group. Blood 111, 1044-1053.

Lee, D.W., Kochenderfer, J.N., Stetler-Stevenson, M., Cui, Y.K., Delbrook, C., Feldman, S.A., Fry, T.J., Orentas, R., Sabatino, M., Shah N.N., Steinberg, S.M., Stroncek, D., Tschernia, N., Yuan, C., Zhang, H., Zhang, L., Rosenberg, S.A., Wayne, A.S., and Mackall, C.L. (2015). T cells expressing CD19 chimeric antigen receptors for acute lymphoblastic leukaemia in children and young adults: a phase 1 doseescalation trial. Lancet 385,517-528.

Moritz, D., Wels, W., Mattern, J., and Groner, B. (1994). Cytotoxic T lymphocytes with a grafted recognition specificity for ERBB2ressing tumor cells. Proc Natl Acad Sci USA 91, 4318-4322.

Jena, B., Dotti, G., and Cooper, L.J. (2010). Redirecting T-cell specificity by introducing a tumor specific chimeric antigen receptor. Blood 116 , 1035-1044.

Jensen, M.C., Popplewell, L., Cooper, L.J., DiGiusto, D., Kalos, M.,Ostberg, J.R., and Forman, S.J. (2010). Antitransgene rejection responses contribute to attenuated persistence of adoptively transferred CD20/CD19-specific chimeric antigen receptor redirected $\mathrm{T}$ cells in humans. Biol Blood Marrow Transplant16, 1245-1256.

Jin, Z., Maiti ,S., Huls, H., Singh, H., Olivares, S., Mátés, L., Izsvák, Z., Ivics, Z., Lee, D.A., Champlin, R.E., and Cooper, L.J. (2011). The hyperactive Sleeping Beauty transposase SB100X improves the genetic modification of $\mathrm{T}$ cells to express a chimeric antigen receptor. Gene Ther 18, 849-856.

Kershaw, M.H, Westwood, J.A., Parker, L.L., Wang, G., Eshhar, Z., and Mavroukakis, S.A. (2006). A phase I study on adoptive immunotherapy using gene-modified $\mathrm{T}$ cells for ovarian cancer. Clin Cancer Res 12, 6106-6115.
Kochenderfer, J.N., Dudley, M.E., Feldman, S.A., Wilson, W.H., Spaner, D.E., and Maric, I. (2012). B-cell depletion and remissions of malignancy along with cytokineassociated toxicity in a clinical trial of anti-CD19 chimeric-antigen-receptor-transduced T cells. Blood 119, 2709-2720.

Mardiros, A., Dos Santos, C., McDonald, T., Brown, C.E., Wang, X., Budde, L.E., Hoffman, L., Aguilar, B., Chang, W.C., Bretzlaff, W., Chang, B., Jonnalagadda, M., Starr, R., Ostberg, J.R., Jensen, M.C., Bhatia, R., and Forman, S.J. (2013). T cells expressing CD123-specific chimeric antigen receptors exhibit specific cytolytic effector functions andantitumor effects against human acute myeloid leukemia. Blood $122,3138-3148$.

Maude, S.L., Frey, N., Shaw, P.A., Aplenc, R., Barrett, D.M., Bunin, N.J., Chew, A., Gonzalez, V.E., Zheng, Z., Lacey, S.F., Mahnke, Y.D., Melenhorst, J.J., Rheingold, S.R., Shen, A., Teachey, D.T., Levine, B.L., June, C.H., Porter, D.L., and Grupp, S.A. (2014). Chimeric antigen receptor T cells for sustained remissions in leukemia. N Engl J Med 371, 1507-1517.

Maus, M.V., Grupp, S.A., Porter, D.L., and June, C.H. (2014). Antibody-modified T cells: CARs take the front seat for hematologic malignancies. Blood 123, 2625-2635.

Ritchie, D.S., Neeson, P.J., Khot, A., Peinert, S., and Tai T. (2013). Persistence and efficacy of second generation CAR- T cell against the LeY antigen in acute myeloid leukemia. Mol Ther 21, 2122-2129.

Scholler, J., Brady, T.L., and Binder-Scholl, G. (2012). Decade-long safety and function of retroviralmodified chimeric antigen receptor $\mathrm{T}$ cells. SciTransl Med 4, 132ra153.

Teng, M.W., Kershaw, M.H., Moeller, M., Smyth, M.J., and Darcy, P.K. (2004). Immunotherapy of cancer using systemically delivered genemodified human T lymphocytes. Hum Gene Ther 15, 699-708.

Till, B.G., Jensen, M.C., Wang, J., Chen, E.Y., Wood, B.L., Greisman, H.A., Qian, X., James, S.E., Raubitschek, A., Forman, S.J., Gopal, A.K., Pagel, J.M., Lindgren, C.G., Greenberg, P.D., Riddell, S.R., and Press, O.W. (2008) Adoptive immunotherapy for indolent non-Hodgkin lymphoma and mantle cell lymphoma using genetically modified autologous CD20-specific T cells. Blood 112, 2261-2271.

Wen, Y.J., Min, R., Tricot, G., Barlogie, B., and Yi, Q. (2002). Tumor lysate-specific cytotoxic $\mathrm{T}$ lymphocytes in multiple myeloma: promising effector cells for immunotherapy. Blood 99, 3280-3285.

Open Access This article is distributed under the terms of the Creative Commons Attribution License which permits any use, distribution, and reproduction in any medium, provided the original author(s) and source are credited. 